\title{
Shaping Tolerant Attitudes towards Immigrants: \\ The Role of Welfare State Expenditures
}

\author{
Carolin Rapp \\ Accepted for publication in the Journal of European Social Policy
}

\begin{abstract}
This article contributes to the ongoing discussion on how tolerance may be fostered in Western European countries and to the question of how contextual factors such as welfare state expenditures may contribute to this formation. Tolerance is understood as a basic democratic principle that helps civil societies cope with rising levels of diversity stemming from increased immigration and individualism. Within the tolerance literature it is commonly agreed upon that a comprehensive welfare state is capable of bridging class divides and overcoming social categorization. However, over the past decades European welfare states experienced an ongoing influx of immigrants, challenging their general purpose and increasing notions of 'welfare chauvinism'. Drawing on insights from both tolerance and welfare state solidarity literature, we implement hierarchical analyses based on Eurobarometer data to assess the potential influence of welfare state universalism on political and social tolerance in 15 Western European countries. Moreover, we demonstrate that this relationship is highly conditional on the degree of ethnic heterogeneity within a country.
\end{abstract}

Keywords: welfare state, political tolerance, social tolerance, ethnic diversity, Western Europe 


\section{Introduction}

The relationship between immigrants, immigration, and the welfare state is one of the most frequently discussed issues in the social sciences (Eger, 2010; Emmenegger and Klemmensen, 2013; Finseraas, 2008; Mau and Burkhardt, 2009; van Oorschot and Uunk, 2007; van der Waal et al., 2013). Three main research strands can be identified: First, studies focusing on the 'welfare magnet hypothesis', implying that highly developed welfare states attract a larger number of immigrants than less comprehensive welfare states (e.g. Nannestad, 2007); second, research concentrating on the analysis of welfare chauvinism as well as the question of whether immigration and ethnic diversity undermine the majority's support for welfare redistribution (Eger, 2010; Emmenegger and Klemmensen, 2013; Finseraas, 2008; Mau and Burkhardt, 2009; van Oorschot and Uunk, 2007; van der Waal et al., 2013); and third, research on the influence from welfare state institutions and spending on attitudes towards immigrants (Crepaz and Damron, 2009; Kirchner et al., 2011; Marquart-Pyatt and Paxton, 2007). In this paper, we focus on the last point. However, we further aim to integrate insights from the first two research strands to enhance the knowledge about the role of welfare states in forming attitudes towards immigrants.

It is generally agreed upon that one of the fundamental purposes of comprehensive welfare states is to overcome existing social and economic differences by providing public goods which bridge existing class divides (Crepaz and Damron 2009). With increasing immigration, however, welfare states are facing new challenges as growing ethnic diversity changes the social composition of European societies. Eger (2010) as well as Mau and Burkhart (2009) already showed that rising levels of ethnic heterogeneity decrease welfare state solidarity. We thus argue that the assumed positive effect of welfare states on the formation of tolerance (Crepaz and Damron, 2009; Kirchner et al., 2011) may not hold for highly ethnic diverse countries. Following the approach by van Oorschot and Uunk (2007) who scrutinized the relationship between welfare state spending and the public's concern for immigrants, we extend their study by combing insights from the welfare state solidarity literature with evidence from tolerance research. In contrast to most of the recent research on tolerance, we go beyond the question of anti-immigrant attitudes (see e.g. Hjerm, 2009; Quillian, 1995; Schneider, 2008) by asking how tolerance may combat these negative attitudes. While previous studies have evaluated how welfare state expenditures impact immigrant-specific prejudice (among others Dunn et al., 2009; Kirchner et al., 2011), contributions 
analyzing how these prejudices can be resolved are rare (see e.g. Freitag and Rapp, 2013). Filling this research gap we ask the question of how the welfare state may shape tolerant attitudes towards objectionable groups and what role the overall ethnic diversity plays in this context.

Our results challenge the notion that comprehensive welfare states are able to increase tolerant attitudes in terms of the willingness to permit political and social rights to an objectionable group. It appears that in more diverse and ethnically heterogeneous countries status anxieties and social security feelings may not be assuaged by an extensive welfare state. The fear that the welfare state is exploited by increased immigration undermines the hitherto positive effects from welfare state expenditures on tolerance towards immigrants.

In the next section we present our conceptualization of tolerance in a rejection and acceptance component, followed by the discussion on the possible influences from welfare state universalism on political and social tolerance. In the fourth section, we elaborate on the methodology used and subsequently subject our main predications to systematic empirical testing. The most important findings are summarized and discussed in the fifth section. Finally, a conclusion completes the article.

\section{The nature of tolerance toward immigrants}

Tolerance is mainly understood as the willingness to "put up with" others one objects to (e.g. Forst, 2003, 2007; Gibson, 1992, 2006; Mutz, 2001; Sullivan et al., 1993; Stouffer 1955). This definition implies that disapproval or objection necessitates tolerance (Sullivan et al., 1993, 4). One can only be tolerant if he or she first rejects a group and then grants them certain political rights, despite the fact he or she finds this group objectionable. In this regard, tolerance is a sequential concept (Ferrar, 1976) consisting of both a rejection and an acceptance component, with rejection signifying the anti-immigrant attitude and acceptance a potential means to overcome these negative attitudes without completely eliminating them. ${ }^{1}$

\footnotetext{
${ }^{1}$ While we focus on the philosophical definition of tolerance (see especially Forst, 2003, 2007) there are other tolerance conceptualizations within social science literature. One of the most prominent one is the more inclusive definition, expressing a friendly and trustful attitude toward other people reflected in a "non-negative general orientation toward groups outside of one's own" (Dunn et al. 2009, 284; Kirchner et al., 2011, 205; Sniderman et al., 1989). Following the logic of Allport $(1958,398)$ and others, this signifies the warmer notion of tolerance compared to the conventional definition of tolerance as the endurance of a person, group, activity, idea or organization of which or whom one does not approve (see King, 1998: 21). We, however, follow the traditional approach as we are interested in the act of overcoming negative attitudes by accepting the objectionable.
} 
Scanlon $(2003,187)$, for example, states, that "tolerance is an attitude that is intermediate between wholehearted acceptance and unrestrainable rejection." More generally, this tolerance dimension incorporates accepting the disagreeable. Tolerance, in this sense, is the ability to put up with something potentially disagreeable, such as enhanced influx of immigrants into one's country.

In this paper we focus exclusively on tolerance toward different immigrant groups, for the currently rising levels of immigration confront individuals with increasing cultural and ethnic diversity that may challenge the public's general acceptance of immigrants. Moreover, the perception prevails that immigrants threaten important values or constitute a danger to a country's economic situation (Freitag and Rapp, 2013; Gibson 1992, 569; Stouffer, 1955; Sullivan et al. 1993, 78-79, 186). An extensive literature has further shown that anti-immigrant attitudes are a dominant issue in social science research (Hjerm, 2009; McLaren, 2003; Quillian, 1995; Scheepers et al., 2002; Schneider, 2008). Based on our tolerance conceptualization we are able to analyze how these anti-immigrant attitudes are formed (rejection component), as well as how they may be overcome by granting immigrants certain rights and activities despite an initial objection. As a major challenge in today's societies involves tolerating those one may find objectionable, tolerance thus goes a step beyond anti-immigrant attitudes by asking for the acceptance of such groups. Tolerance is a means of overcoming the challenges societies face with regard to increasing diversity and diverging values. Here tolerance builds the base of a peaceful co-existence, since "the more tolerant citizens are of the rights of others, the more secure are the rights of all” (Nevitte, 1996, 58; Sniderman et al., 1989, 25). It is therefore not only a generally important social value and democratic virtue, but also constitutes a necessity for modern, free, and open societies. We further distinguish between political and social tolerance. Political tolerance incorporates democratic principles such as the guaranteeing of political rights and freedom to all societal groups. In contrast, social tolerance is mainly concerned with activities in one's personal surrounding. According to Norris $(2002,158)$ social tolerance is "the willingness to live and let live" as well as the toleration of diverse life-styles.

\section{How does the welfare state relate to tolerance?}

Hitherto, research on tolerance mainly focusses on influence factors on the individual or group level. The most commonly used theoretical explanations are the social identity theory, conflict theory, and contact 
theory. However, it is generally agreed upon that individual attitudes and behaviour, such as tolerance, are decisively influenced by contextual premises (Freitag 2006; Huckfeldt 1986). Previous studies have shown that institutional settings such as the welfare regime (e.g. Crepaz and Damron, 2009; Kirchner et al., 2011), the political system (e.g. Dunn et al., 2009; Peffley and Rohrschneider; Weldon, 2006) as well as economic factors (e.g. Andersen and Fetner, 2008) contribute to the formation of tolerance. In the following, we present our arguments concerning the question of how welfare state universalism relates to the formation of social and political tolerance. We thereby rely on the central assumptions of neo-institutionalism: "political institutions are capable of moulding individual preferences and stimulating [...] behavioural options and affective orientations toward others by means of certain incentive mechanisms" (Kirchner et al. 2011, 208; see also Hall and Taylor 1996). ${ }^{2}$ Or as Larsen (2008: 148) states: “The institutional structure of the different welfare regimes influences or - using another terminology - frames the way the public perceives the poor and the unemployed" or - in our case - ethnic minorities and immigrants.

The question arises as to how and why an extensive welfare state should increase political and social tolerant attitudes. The mechanism is rooted in the basic attribute of a generous welfare state to contribute to feelings of security and the reduction of individual status anxieties. Extensive and universal welfare states should thus foster solidarity across different societal groups and promote the sense of a common community (Esping-Andersen 1990; van Oorschot and Uunk 2007; van der Waal et al. 2013). According to Crepaz and Damron $(2009,438)$ an extensive welfare state is capable of bridging the class divide by providing general public goods such as health care, education, and security. Universal welfare states therefore include all social classes and groups (Lijphart, 1999; Kirchner et al., 2011: 211). The overall aim of a universal welfare policy is thus to prevent discrimination between citizens and social categorization based on neediness (Rothstein and Stolle, 2003: 196). In doing so, extensive welfare states diminish individual (and group-based) status anxieties and the general fear of losing one's social status or being disadvantaged in relation to other groups by guaranteeing a minimum level of social security. As a consequence, this feeling of security should further reduce the danger of becoming intolerant toward others (Fritzsche, 1995: 16; Feldmann et al., 2000; Kirchner et al., 2011: 209; Tatalovich and Smith, 2001).

\footnotetext{
${ }^{2}$ It may be arguable whether welfare state universalism signifies a typical political institution as it rather represents the quality/performance of the welfare state. However, and in contrast to traditional institutionalisms, the neoinstitutional approach explicitly includes informal settings and rules such as welfare state expenditures.
} 
In other words, as long as individuals see their own social status protected by the given institutional settings, tolerance will be affordable for them (Feldmann et al., 2000; Kirchner et al., 2011). On the contrary, if basic personal and social needs are not protected, individuals' will demand for personal selfexpression and the limitation of the rights for others (i.e. intolerance). In a surrounding with prevailing insecurities and status anxieties, individuals will fear losing their societal positions and should be more likely to deny certain political and social rights to groups they dislike. In a more comprehensive and universally orientated surrounding, individuals should thus be more likely to guarantee social and political rights to groups they feel objectionable to. Prior research by Kirchner et al. (2011), Crepaz and Damron (2009) as well as Marquart-Pyatt and Paxton (2007) already underlined the positive effect from welfare state expenditures on tolerant attitudes toward diverse groupings. Based on these insights and our theoretical reasoning we formulate the following hypothesis:

Hypothesis 1: Higher levels of political and/or social tolerance are fostered by more extensive welfare states.

This assumption, however, may not be true for diverse and heterogeneous societies. Throughout the last decades European countries have experienced rising levels of immigration and, consequently, growing ethnic, linguistic, and religious heterogeneity. Such high levels of diversity may attenuate the positive effects of welfare state universalism, as the majority of the population may fear that their country's social welfare system will be exploited by growing numbers of immigrants. Moreover, studies on welfare state solidarity and welfare chauvinism agree that high levels of immigration diminishes the majority's support for welfare distribution for ethnic minorities in their country (Emmenegger and Klemmensen 2013; Mau and Burkhardt 2009; van Oorschot and Uunk 2007; van der Waal et al., 2013). These assumptions follow the "homophile principle," which posits that individuals prefer to interact socially with others who are similar to themselves. This idea implies that there is a general negative perception of people who are seen as different. The social identity theory (Tajfel, 1982; Tajfel and Turner, 1979) assumes that social groups based on social categorization along basic cleavage lines (race, ethnicity, religion, language, culture, and class) emerge that identify themselves as potential in- and out-groups (see also Weldon, 2006). Social categorization thus refers to "our tendency to divide the world into two distinct categories, 'us' and 'them"” (Baron, 1989: 643; Crepaz and Damron, 2008: 445). Accordingly, individuals perceive their in-group, i.e. 
the majority within a given country, as superior to an existing out-group such as immigrants or ethnically diverse groupings. They will be more willing to grant certain rights to their own rather than to other groups. Moreover, as the opposing group increases in size, inter-group conflict should also increase due to growing competition over specific economic and/or cultural resources. The social categorization process may thus lead to discriminatory behavior between groups. Gibson and Gouws underscore the effects from this group distinctiveness in their research on inter-group tolerance in South Africa (2000: 278): "Strong in-group positive identities create strong out-group negative identities, which are in turn connected to antipathy toward one's political opponents, perceptions that those opponents are threatening, and, ultimately, to political intolerance". Concerning our research question, this would indicate that in countries with high ethnic heterogeneity the distinctiveness between groups and thus also the competition for public goods is more pronounced than in more homogeneous countries. As a consequence, in-groups should be inclined to limit general public goods, such as welfare spending, to themselves and will try to exclude out-groups from these benefits. For example, Eger (2010) as well as Mau and Burkhardt (2009) show that rising levels of ethnic heterogeneity decreases the welfare state solidarity for immigrants in Western European countries, even in highly universalistic welfare states such as Sweden. In-group members, i.e. the majority population, will deny welfare state benefits for immigrants if they see themselves and their social status threatened by rising immigration (van Oorschot and Uunk 2007; van der Waal et al. 2013). Moreover, as immigrants in Western European countries tend to be lower skilled, they are often perceived as more reliant on welfare benefits than others (Mau and Burkhardt 2009: 214; Boeri et al. 2002). Keeping the preceding argument in mind, we hypothesize that in countries with high ethnic heterogeneity, the effect of welfare state universalism on political as well as on social tolerance is moderated by the degree of ethnic diversity within a country.

Hypothesis 2: The hypothesized positive effect of welfare expenditures on social and political tolerance diminishes with increasing levels of ethnic heterogeneity in a country.

\section{Data, method, and descriptive statistics}

To test both of our hypotheses we rely on data from the Eurobarometer Survey from 1997, 47.1 (Melich, 1997; see also Weldon, 2006) that covers 15 Western European countries. This survey comprises one of 
the only available comparative data sets that captures tolerance according to its sequential nature. Our aim is to analyse the overcoming of existing prejudice and animosities by means of accepting the objectionable (true tolerance). Thus, we have to rely on a data set which covers both components of tolerance (Freitag and Rapp, 2013; Sullivan et al., 1993). Accordingly, the respondent, is first asked whether she feels any objection toward a group within her country that is ethnically, religiously, or culturally diverse from him or herself (in the following this group will be indicated as a "different ethnic group"). Only individuals who identify an objectionable group fulfil the necessary condition for tolerance, as tolerance requires objection (Sullivan et al., 1993). In a second step, the depth of political tolerance is captured by the following five statements based on the question of whether certain rights and freedoms "should apply equally to people [the objected (minority) group] and to the rest of the population, or only to the rest of the population"

1. Freedom of speech

2. Freedom of association

3. Religious liberty and freedom of conscientiousness

4. Equality before the law

5. The right to vote and be a candidate in political elections;

Political tolerance depicts the willingness to grant an objectionable group with the same political rights as the native population (Gibson, 1992, 2013; Peffley and Rohrschneider, 2003; Sullivan et al., 1993; Weldon, 2006). In a similar way, social tolerance is measured based on these five questions:

1. If people from this [ethnic group] lived in your neighborhood, would you find this difficult to accept, or not?

2. If a suitably qualified person from this [ethnic group] became your boss, would you find this difficult to accept, or not?

3. If you had a child who wanted to marry a person from this [ethnic group], from the same socioeconomic background as yours, would you find it difficult to accept him or her in your family or not?

4. If your child had children by a person from this [ethnic group], would you find this difficult to accept, or not?

5. Could you imagine having a close personal relationship with someone from this [ethnic group], or not?

In contrast to political tolerance, the social tolerance measurement captures the acceptance of diverse others in a respondent's personal surrounding. Both political and social tolerance are captured in additive indices ranging from $0=$ completely intolerant to $5=$ completely tolerant in terms of guaranteeing all five rights/activities to the disliked group (see also Weldon, 2006 who implemented an identical measurement using this data set). In table 1 the mean levels of both political and social tolerance in each of the 15 
Western European countries are displayed. ${ }^{3}$ At first glance, we can observe that political tolerance is generally higher than social tolerance throughout the 15 countries. It seems easier to guarantee certain political rights than to accept a person from an objectionable group in one's immediate surroundings. Sniderman et al. (1989), for example, refer to political tolerance as principled tolerance. According to the authors, principled tolerance originates from the incorporation of democratic principles and their application to all societal and political groups without exception.

Table 1: Social and political tolerance towards ethnically diverse groups in 15 Western European countries

\begin{tabular}{lccc}
\hline & mean social tolerance & mean political tolerance & $N$ \\
\hline Belgium & 1.72 & 2.58 & 604 \\
Ireland & 1.83 & 3.91 & 263 \\
Austria & 1.86 & 3.20 & 493 \\
Germany & 1.91 & 3.33 & 1,037 \\
Greece & 2.06 & 3.96 & 744 \\
Portugal & 2.06 & 3.77 & 410 \\
Italy & 2.08 & 3.74 & 485 \\
Sweden & 2.21 & 3.89 & 566 \\
Denmark & 2.28 & 3.67 & 799 \\
France & 2.42 & 3.19 & 645 \\
United Kingdom & 2.64 & 3.92 & 620 \\
Finland & 2.64 & 4.17 & 571 \\
Spain & 2.67 & 4.30 & 536 \\
Netherlands & 2.75 & 4.17 & 752 \\
Luxembourg & 3.02 & 3.66 & 161 \\
overall mean & $\mathbf{2 . 2 7}$ & $\mathbf{3 . 7 0}$ & $\mathbf{8 , 6 8 6}$ \\
\hline
\end{tabular}

We capture our main explanatory variable, welfare state universalism, by the health care expenditures as well as the unemployment expenditures as percentage of a country's GDP. Although most studies analysing welfare state expenditures rely on the overall spending, we argue that total government spending is considered to be "too broad" a measure for the size of the welfare state (Clayton and Pontusson, 1998: 78). Health care expenditures in particular are a high-quality universal program that increases the feeling of general security and equal opportunities among large segments of the population by satisfying basic needs (Clayton and Pontusson, 1998: 80f.; Kirchner et al., 2011: 212; Rothstein and Uslaner, 2005: 63). ${ }^{4}$ Ethnic heterogeneity, our moderating variable, is captured by the Herfindahl fractionalization index, which is the most commonly used index for measuring aggregate ethnic diversity: $H I=1-\sum_{i=1}^{N} s_{i j}^{2}$, where $s_{i j}^{2}$ is the

\footnotetext{
${ }^{3}$ Only native citizens or those holding the citizenship of the respective country where asked whether they can identify any diverse group in their country that they dislike.

4 As a robustness check we further estimated all our models with the total social expenditures as explanatory variables (see Table A3 in the Appendix). The results, however, do not significantly differ.
} 
share of the group $i(i=1 \ldots n)$ in country $j$. The (ethnic) Herfindahl Index measures the probability that two randomly chosen individuals in country $j$ are different with regard to their ethnicity. The index ranges from 0 to 1 , whereby higher values indicate higher ethnic heterogeneity. Table 2 presents the average values for each analysed country for our main explanatory variables, health care, and unemployment expenditures, as well as ethnic heterogeneity. The expenditures as well as ethnic heterogeneity show considerable variances throughout the 15 countries.

Table 2: Welfare state expenditures and ethnic heterogeneity in 15 Western European countries

\begin{tabular}{lccc}
\hline & $\begin{array}{c}\text { bealth expenditure as } \% \\
\text { of GDP }\end{array}$ & $\begin{array}{c}\text { unemployment } \\
\text { expenditure as } \% \text { of } \\
\text { GDP }\end{array}$ & ethnic heterogeneity \\
\hline Greece & 4.47 & 0.40 & 0.16 \\
Denmark & 4.56 & 4.43 & 0.08 \\
Portugal & 4.71 & 0.91 & 0.05 \\
Ireland & 4.81 & 1.81 & 0.12 \\
Italy & 5.13 & 0.69 & 0.11 \\
Luxembourg & 5.14 & 0.50 & 0.53 \\
Spain & 5.37 & 3.17 & 0.42 \\
United Kingdom & 5.63 & 1.17 & 0.12 \\
Finland & 5.66 & 3.91 & 0.13 \\
Netherlands & 5.91 & 2.82 & 0.11 \\
Austria & 5.94 & 1.27 & 0.11 \\
Sweden & 6.24 & 2.27 & 0.06 \\
Belgium & 6.46 & 3.23 & 0.55 \\
France & 7.41 & 1.61 & 0.1 \\
Germany & 8.16 & 1.54 & 0.17 \\
overall mean & $\mathbf{5 . 7 1}$ & $\mathbf{1 . 9 8}$ & $\mathbf{0 . 1 9}$ \\
\hline
\end{tabular}

Regarding our conceptualization of tolerance as a sequential concept consisting of a rejection and an acceptance component, we are confronted with a methodological challenge: our tolerance measurement leads to a non-randomly selected sample, as only those individuals who state an objection towards an (ethnic) group are included in the outcome model (depth of political and social tolerance) (see Mondak and Sanders, 2003). Following Sullivan et al. (1993), one way of solving t this problem would be to regress both the group selection and the depth of tolerance on the independent variables. ${ }^{5}$ However, two separate regressions cannot account for the possible omitted variable bias. We only observe the outcome variable (tolerance) if the criterion of group selection is met. Consequently, with this kind of procedure we would

\footnotetext{
${ }^{5}$ Sullivan et al. $(1993,250)$ show in separate analyses for the rejection and acceptance component that socio-economic variables (sex, age, education, race, class, etc.) are assumed to affect only the probability of selecting an objectionable group, but not the assignment of societal rights to the least-liked group. According to the authors, the depth of tolerance is particularly influenced by variables identifying certain political or psychological variables.
} 
not control for factors that led to this group selection (Vella, 1998). A powerful method to simultaneously diminish the selection problem as well as the omitted variable bias is to implement a two-step Heckman procedure (Heckman, 1979; Freitag and Rapp, 2013) as this procedure follows the assumption that the first step (the selection stage) indirectly influences the results on the outcome stage. The clear advantage is that although we estimate two separate models like Sullivan et al. (1993), we account for the results of the first stage in the outcome stage with the use of the inverse Mills ratio. Here, the first step comprises a multilevel probit model where the group selection (rejection component) is regressed on the socioeconomic control variables (SES) as well as political and psychological variables which are said to influence attitudes toward immigrants, namely sex, age, education, threat perceptions, ethnic diversity among friends, general attitudes towards minorities, and political ideology. Based on this probit model, the inverse Mills ratio (IMR) is computed for each observation of the selected sample. ${ }^{6}$ This estimates the selection probability and will be integrated in the second step as an instrument to control for sample selection. ${ }^{7}$ In the second regression the inverse Mills ratio is added to the confounding variables of threat perceptions, number of foreigners among friends, and political ideology as well as our main explanatory variables on welfare universalism. ${ }^{8}$ On the contextual level we further control for the economic prosperity with the help of the $(\log )$ GDP. The reasoning is that even rich countries may not have an extensive welfare state and still tend to attract more immigrants. All included confounding variable contribute to the overall model fit and help in minimizing the standard errors of our main estimates (Clarke, 2012). An overview over all implemented variables is given in table A1 in the appendix. In line with our data structure and our research question, we use hierarchical models with interactions on the second level (contextual level) to test our hypotheses.

\footnotetext{
${ }^{6}$ The inverse Mills ratio is computed according to the following equation: $\hat{\lambda}_{i}=\frac{\phi\left(\omega_{i} \widehat{\gamma}\right)}{\Phi\left(\omega_{i} \widehat{\gamma}\right)}$; it estimates the ratio of the probability density function over the cumulative distribution function of a (truncated normal) distribution (Heckman, 1979). In other words, the inverse Mills ratio incorporates the estimated probability of selecting a group as objectionable based on the implemented explanatory variables. By implementing this ratio in our second regression, which estimates the probability to grant certain rights and activities to an objectionable group, we control for the prior selection probability.

7 The selection problem is based on missing values on the dependent variable that are conditional on certain independent variables and thus lead to a biased inference (Heckman, 1979; Winship and Mare, 1992, 328). The basic idea is that the first step (the selection stage) influences the results on the outcome stage.

${ }^{8}$ Some may argue that threat perceptions and tolerance are very similar concepts that may load on one single factor. Further analyses (not shown here, available one request) show that these two concepts are closely related, but do not construct one single factor. For example, the correlation between social tolerance and threat perceptions is $\rho=$ -.40 revealing a connection between these concepts. Besides these empirical considerations, existing literature underscores the conceptual difference of these concepts (see especially Sullivan et al., 1993).
} 


\section{Results}

How do welfare state expenditures relate to the formation of political and social tolerance in Western European countries? To answer this question we first implement models testing for the direct effect of welfare state expenditures on social and political tolerance, respectively (see models 1 and 4). To test our second hypothesis that the degree of ethnic heterogeneity in a country moderates the relationship between welfare state universalism and tolerance, we introduce interactions between ethnic heterogeneity and the respective welfare state expenditure to our models (models 2, 3 and models 5, 6). All results are given in table 3. The inverse Mills ratio in all six models is based on the first-stage regression presented in table A2 in the Appendix which controls for the possible sample selection.

To begin, we see in model 1 as well as in model 4 that health care expenditures exhibit a negative effect on social as well as political tolerance. However, only the coefficient for the effect of health care expenditures on political tolerance reaches statistical significance. While unemployment expenditures effects are slightly positive (as hypothesized) it does not reach statistical significance in both models. Turning to our control variables on the individual-level we see that respondents who feel less threatened by immigrants, have at least some foreign friends, and who support the political left will be significantly more tolerant. The inverse Mills ratio has a negative sign and a significant impact on both social and political tolerance. This means that respondents with a high probability to objection to an ethnic group are less likely to be tolerant. This is in line with our assumptions.

However, the results concerning the welfare state universalism do not unambiguously support hypothesis 1: Although generous welfare states are said to overcome social categorization and are capable of overcoming class divides (Crepaz and Damron, 2009; Kirchner et al., 2011), it seems as if they do not foster tolerant attitudes. Our results may challenge the findings by Crepaz and Damron (2009), Kirchner, Freitag, and Rapp (2011), and Marquart-Pyatt and Paxton (2007) who score the positive effects of welfare 
state universalism on tolerance and/or anti-immigrant attitudes. ${ }^{9}$ One possible explanation for these rather

Table 3: Social and political tolerance - ML-Regression results

\begin{tabular}{|c|c|c|c|c|c|c|}
\hline & \multicolumn{3}{|c|}{ social tolerance } & \multicolumn{3}{|c|}{ political tolerance } \\
\hline & $\begin{array}{l}\text { model } 1 \\
\text { est. (se) }\end{array}$ & $\begin{array}{c}\text { model } 2 \\
\text { est. (se) }\end{array}$ & $\begin{array}{c}\text { model } 3 \\
\text { est. (se) }\end{array}$ & $\begin{array}{l}\text { model } 4 \\
\text { est. (se) }\end{array}$ & $\begin{array}{l}\text { model } 5 \\
\text { est. (se) }\end{array}$ & $\begin{array}{c}\text { model } 6 \\
\text { est. (se) }\end{array}$ \\
\hline $\begin{array}{l}\text { individual level } \\
\text { threat perception }\end{array}$ & $\begin{array}{c}-2.20^{* * *} \\
(0.11)\end{array}$ & $\begin{array}{c}-2.20^{* * *} \\
(0.11)\end{array}$ & $\begin{array}{c}-2.20^{* * *} \\
(0.11)\end{array}$ & $\begin{array}{c}-1.04 * * * \\
(0.08)\end{array}$ & $\begin{array}{c}-1.04 * * * \\
(0.08)\end{array}$ & $\begin{array}{c}-1.04^{* * *} \\
(0.08)\end{array}$ \\
\hline $\begin{array}{l}\text { no. of foreigners am } \\
\text { friends (ref. }=\text { none) }\end{array}$ & & & & & & \\
\hline some & $\begin{array}{c}0.34 * * * \\
(0.05)\end{array}$ & $\begin{array}{c}0.34 * * * \\
(0.05)\end{array}$ & $\begin{array}{c}0.34 * * * \\
(0.05)\end{array}$ & $\begin{array}{c}0.21 * * * \\
(0.04)\end{array}$ & $\begin{array}{c}0.20^{* * *} \\
(0.04)\end{array}$ & $\begin{array}{c}0.21 * * * \\
(0.04)\end{array}$ \\
\hline a lot & $\begin{array}{c}0.89 * * * \\
(0.09)\end{array}$ & $\begin{array}{c}0.88^{* * *} \\
(0.09)\end{array}$ & $\begin{array}{c}0.89 * * * \\
(0.09)\end{array}$ & $\begin{array}{c}0.16 \\
(0.09)\end{array}$ & $\begin{array}{c}0.15 \\
(0.09)\end{array}$ & $\begin{array}{c}0.15 \\
(0.09)\end{array}$ \\
\hline political ideology & $\begin{array}{c}-0.12 * * * \\
(0.01)\end{array}$ & $\begin{array}{c}-0.12 * * * \\
(0.01)\end{array}$ & $\begin{array}{c}-0.13 * * * \\
(0.01)\end{array}$ & $\begin{array}{c}-0.04 * * * \\
(0.01)\end{array}$ & $\begin{array}{c}-0.04 * * * \\
(0.01)\end{array}$ & $\begin{array}{c}-0.04 * * * \\
(0.01)\end{array}$ \\
\hline inverse Mills ratio & $\begin{array}{c}-3.44 * * * \\
(0.41)\end{array}$ & $\begin{array}{c}-3.44 * * * \\
(0.41)\end{array}$ & $\begin{array}{c}-3.43 * * * \\
(0.41)\end{array}$ & $\begin{array}{l}-0.91^{*} \\
(0.36)\end{array}$ & $\begin{array}{l}-0.92^{*} \\
(0.36)\end{array}$ & $\begin{array}{l}-0.92^{*} \\
(0.36)\end{array}$ \\
\hline $\begin{array}{l}\text { contextual level } \\
\text { health care exp. } \\
\text { in } \% \text { of GDP }\end{array}$ & $\begin{array}{l}-0.08 \\
(0.06)\end{array}$ & $\begin{array}{c}0.13 \\
(0.08)\end{array}$ & & $\begin{array}{c}-0.19 * * \\
(0.06)\end{array}$ & $\begin{array}{c}0.02 \\
(0.10)\end{array}$ & \\
\hline $\begin{array}{l}\text { unemployment exp. } \\
\text { in } \% \text { of GDP }\end{array}$ & $\begin{array}{c}0.03 \\
(0.05)\end{array}$ & & $\begin{array}{l}0.24 * * \\
(0.08)\end{array}$ & $\begin{array}{c}0.03 \\
(0.05)\end{array}$ & & $\begin{array}{c}0.34 * * * \\
(0.09)\end{array}$ \\
\hline ethnic diversity & $\begin{array}{c}1.43 * * * \\
(0.38)\end{array}$ & $\begin{array}{l}9.21 * * * \\
(2.59)\end{array}$ & $\begin{array}{c}3.61 * * * \\
(0.79)\end{array}$ & $\begin{array}{l}-0.18 \\
(0.40)\end{array}$ & $\begin{array}{l}7.34^{*} \\
(2.90)\end{array}$ & $\begin{array}{c}2.79 * * \\
(0.93)\end{array}$ \\
\hline$(\log )$ GDP & $\begin{array}{l}-0.52^{* *} \\
(0.18)\end{array}$ & $\begin{array}{l}-0.58^{* *} \\
(0.14)\end{array}$ & $\begin{array}{c}-0.92 * * * \\
(0.17)\end{array}$ & $\begin{array}{c}-0.50^{* *} \\
(0.19)\end{array}$ & $\begin{array}{c}-0.55^{* * *} \\
(0.16)\end{array}$ & $\begin{array}{c}-1.13^{* * *} \\
(0.20)\end{array}$ \\
\hline $\begin{array}{l}\text { interaction effects } \\
\text { health exp.* } \\
\text { ethnic div. }\end{array}$ & & $\begin{array}{c}-1.34 * * \\
(0.44)\end{array}$ & & & $\begin{array}{c}-1.29 * * \\
(0.50)\end{array}$ & \\
\hline $\begin{array}{l}\text { unempl. exp.* } \\
\text { ethnic div. }\end{array}$ & & & $\begin{array}{c}-0.93 * * * \\
(0.30)\end{array}$ & & & $\begin{array}{c}-1.26^{* * *} \\
(0.36)\end{array}$ \\
\hline intercept & $\begin{array}{c}10.82^{* * *} \\
(1.76)\end{array}$ & $\begin{array}{c}10.22^{* * *} \\
(1.45)\end{array}$ & $\begin{array}{c}13.83^{* * * *} \\
(1.72)\end{array}$ & $\begin{array}{c}11.46^{* * *} \\
(1.83)\end{array}$ & $\begin{array}{c}10.85^{* * *} \\
(1.54)\end{array}$ & $\begin{array}{c}15.99 * * * \\
(1.98)\end{array}$ \\
\hline model component & & & & & & \\
\hline$\sigma^{2} \alpha_{j}$ & 0.04 & 0.02 & 0.02 & 0.05 & 0.03 & 0.04 \\
\hline$\sigma^{2}$ & 2.05 & 2.05 & 2.05 & 1.80 & 1.80 & 1.80 \\
\hline BIC & 21099 & 20836 & 20837 & 20008 & 20083 & 20086 \\
\hline $\mathrm{N}$ (indiv./context) & $5822 / 15$ & $5822 / 15$ & $5822 / 15$ & $5822 / 15$ & $5822 / 15$ & $5822 / 15$ \\
\hline
\end{tabular}

${ }^{9}$ Although our results challenge prior findings, one must keep in mind that we, first, use the Eurobarometer as a data source that covers a different time period; and second, we focus on a very specific form of tolerance and not antiimmigrants attitudes as our dependent variable. These differences may explain the disparities between our results and prior research in this field. 
counterintuitive results may be that the effect is moderated by the degree of ethnic heterogeneity within a country as stated in hypothesis 2 . Models 2 and 3 in table 3 test this assumption for social tolerance, and models 5 and 6 test this conditional hypothesis for political tolerance. The results demonstrate that there is a significant negative interaction between both our welfare expenditure measures and ethnic heterogeneity. This indicates that with growing diversity the effect of welfare universalism on both social and political tolerance becomes more strongly negative. The more interesting question, however, is whether this relation is positive for low levels of ethnic heterogeneity. Following Berry et al. (2012), interaction effects are best interpreted by graphically displaying their marginal effects. Accordingly, the graphical representation of these four interactions is presented in figures 1 and 2, respectively. The solid line represents the effect of welfare expenditures on social or political tolerance for changing levels of ethnic heterogeneity. The dashed lines show the 95\% confidence bands revealing the uncertainty of the estimated result. Furthermore, the distribution of the ethnic heterogeneity is given by the grey shaded area. At first glance, we observe in figure 1 that the conditional effect of health care expenditures on social tolerance changes from a positive sign for low levels of heterogeneity to negative values for highly ethnical diverse countries. The effect, however, only reaches statistical significance for the negative values which represents 40 per cent of the sample. For the other 60 per cent, the effect is not distinguishable from zero, as the confidence intervals include the zero line. A similar result can be observed in the right graph of figure 1: The overall effect of health care expenditures on political tolerance is significantly negative for around 88 per cent of our sample. In other words, in countries with an ethnic heterogeneity larger than an HI value of .07, welfare state expenditures relate negatively to the formation of political tolerance.

Figure 1: The influence of health care expenditures on social and political tolerance for different levels of ethnic heterogeneity
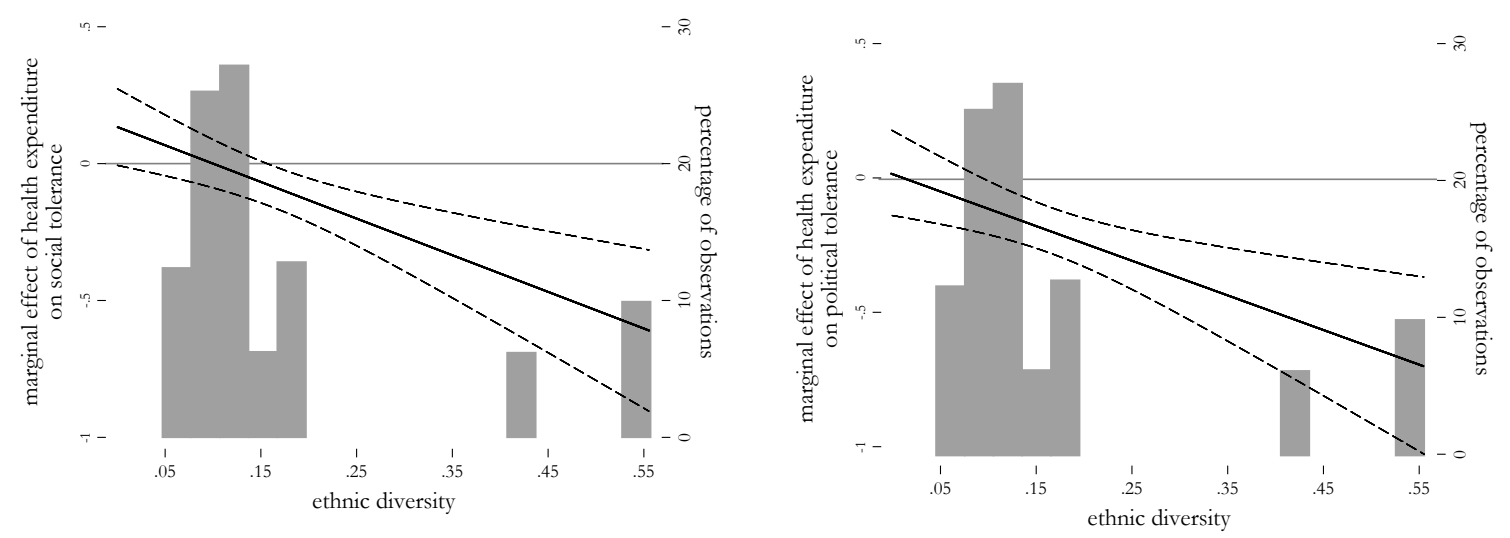
Figure 2 displays the results based on a country's unemployment expenditures. Here the results are more distinguishable, as we observe a significant change of sign: The effect of unemployment expenditures on both social and political tolerance is positive in countries with low levels of ethnic heterogeneity, whereas it becomes negative with higher levels of diversity. More precisely, for the larger part of the sample (about 75 per cent for social as well as for political tolerance) the effect of welfare state universalism on tolerance

Figure 2: The influence of unemployment expenditures on social and political tolerance for different levels of ethnic heterogeneity
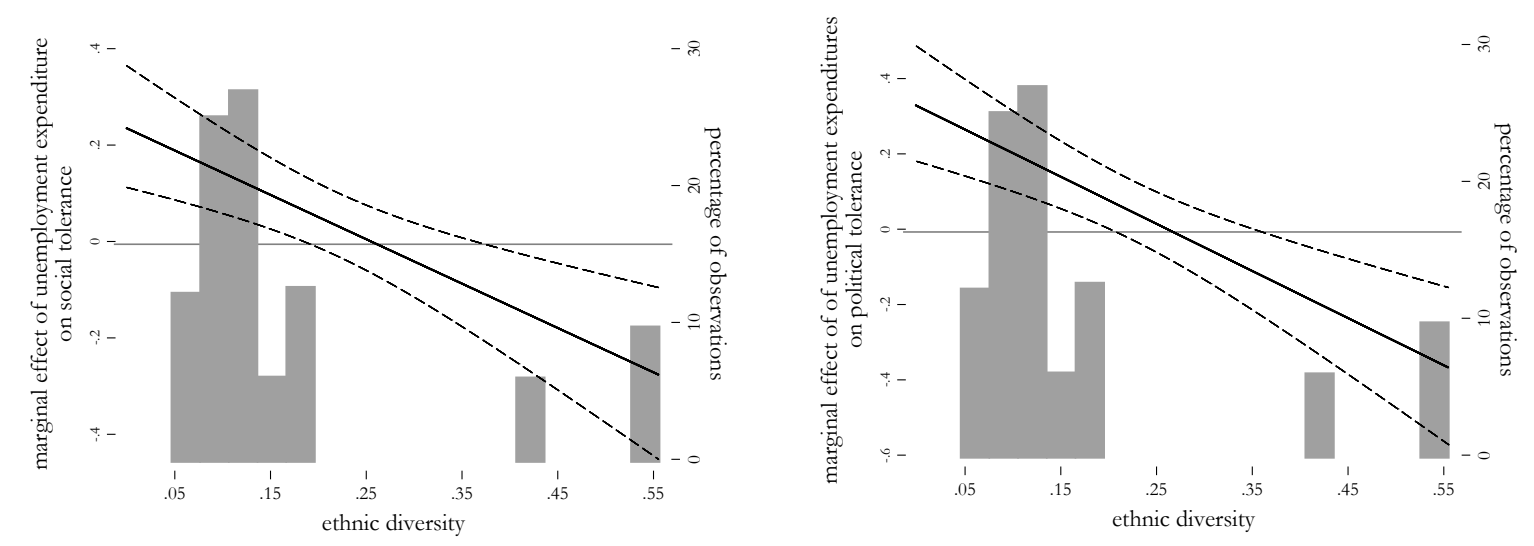

is positive if we take the level of ethnic heterogeneity into consideration. This result supports the reasoning in hypothesis 1 that welfare states are able to reduce status anxieties, thereby rendering tolerance more 'affordable' to the residents in a country. This effect, however, is highly conditional on a country's ethnic composition. As we move higher along the scale of diversity, this positive effect turns negative, indicating that individuals fear losing privileges, such as welfare expenditures, to out-groups and thus try to limit certain political and social right for these out-groups. All four of these interactive effects show a substantive significance in means of a substantial effect size. For example, the interaction between health care spending and ethnic diversity implies that a change in the ethnic composition within a country from 0 to 1 results in 1.34 point lower lever of social tolerance and a 1.29 lower level of political tolerance (this may be similarly interpreted for the interaction effects with unemployment spending). These effect sizes are also displayed by the rather steep slopes in figure 1 and 2. Despite these strong interactive effects, one must notice that the direct effects of welfare state expenditures on social and political tolerance, respectively, are only partly significant. And if so, they show a rather small impact on the formation of 
tolerance. This implies that welfare state expenditures only exhibit a conditional effect on social and political tolerance.

The analyses could show that the effect of welfare state expenditures on tolerance is highly dependent on a country's ethnic heterogeneity. By adding insights from the welfare research to the analysis of institutional influences on tolerance, we could shed more light on this ambiguous relationship. However, the robustness of our results may be questionable given that we only have data for 15 countries. According to Stegmueller (2013) a hierarchical analysis should at least incorporate 30 level-2 units to render robust results. One way of testing the robustness of analyses with a rather small number of cases is by testing for influential cases which could bias our results and may lead to false assumptions. We estimated Cooks Distance (CooksD) as well as dfBetas for our models (see van der Meer et al., 2010). Belgium could be identified as a potential outlier. We re-estimated our models under the exclusion of Belgium and obtained similar or slightly better results than those presented above. Some may further argue that Bayesian estimations could render more precise results. Stegmueller (2013) argues in his paper that conventional ML-estimates in small-N analyses underestimate the confidence intervals by around 5 per cent, although the estimated coefficients are correctly estimated. Our four interaction effects are at least significant at the 5 per cent level, indicating that even if we underestimated the uncertainty by 5 per cent, the effect would still be significant at the 10 per cent level, which remains an acceptable result. Additional analyses (see Appendix) further show that our results remain robust even if we use the total social expenditures as a percentage of the GDP as the measure of welfare state universalism. ${ }^{10}$ These robustness checks however may not rule out a causality issue: We cannot surely say whether universal welfare institutions lead to more tolerant citizens or whether this causal relationship is reversed. We try to rule out the reversed relationship by incorporating a time lag between the measure of welfare state expenditures (as well as ethnic heterogeneity) and their effect on individual social tolerance and political tolerance. In sum, although we have a rather small number of cases at the second level and a potential

\footnotetext{
${ }^{10}$ Some may argue that social expenditures are notoriously problematic and the best measure of the extensiveness of welfare states would be measures covering the programmatic features of a welfare state such as the welfare generosity index by Alan Scruggs. Additional analyses were conducted on the basis of the overall welfare generosity index (results available on request). These revealed quite similar results to the above presented: the total welfare generosity as well as the unemployment generosity exhibit a significant negative direct effect on political tolerance. Further the interaction effects are almost congruent with our current results for political tolerance. The results for social tolerance, however, reach no statistical significance. Despite these results, we refrain from adding the welfare generosity to our estimates as the data is not available for all 15 countries in our sample (Luxemburg is missing).
} 
endogeneity problem, our results show robust and substantive effects. We now know that there is at the very least a strong interactive relationship between welfare state expenditures, ethnic diversity and their effect on social as well as political tolerance. This evidence allows suggesting that universal welfare institutions are (conditionally) related to the formation of social and political tolerance.

\section{Conclusion}

The literature on tolerance has tended to be separated into two parallel research strands: On the one hand, the welfare state literature is convinced that immigration leads to less welfare solidarity and undermines the support for redistribution (Emmenegger and Klemmensen 2013: 407). On the other hand, studies on general attitudes towards immigrants and tolerance in particular support the idea that welfare states are capable of fostering positive evaluations of immigrants by bridging societal gaps and diminishing social categorisation (Crepaz and Damron 2009; Kirchner et al. 2011; Marquart-Pyatt and Paxton, 2007). The aim of this study was to address this research puzzle and shed more light on the relationship between welfare state expenditures and tolerance towards immigrants. First of all, our results challenge the notion that welfare states positively relate to tolerant attitudes towards immigrants. Within diverse and ethnic heterogeneous countries status anxieties and social security feelings may not be compensated by an extensive welfare state. However, we could resolve this rather counterintuitive finding by integrating an interactive hypothesis revealing that the effect of the welfare state on tolerance is dependent on the degree of ethnic diversity within a country.

Compared to prior research on the effect of welfare state expenditures on tolerance we implemented a more thorough tolerance measurement which captures the overcoming of prevalent negative attitudes towards immigrants by granting them certain social and political rights/activities. Tolerance implies that individuals may be prejudiced and still support the political and social inclusion of groups they dislike. Thus, tolerance is a sequential concept, which consists of both a rejection and an acceptance component. The act of acceptance is thereby crucial to sustain democratic norms. In this line, our results are rather alarming, as this basic democratic element may not be achieved by an extensive welfare state. Accordingly, we must discuss the relevance of our findings for the policy arena. At first glance, our results suggest that even the welfare state is no longer able to ease societal conflicts and to establish tolerant attitudes among citizens. The presented results underscore the ongoing conflict between the tendencies towards general 
labour market mobility in the European Union and the societal consequences of enhanced immigration. The price of more mobility between countries seems to be increased welfare chauvinism and less tolerance towards ethnically diverse groupings. In the end, this study indicates that not all universal welfare systems reinforce tolerant attitudes and that researchers in different fields should be more aware of the consequences of enhanced immigration on the relationship between institutional factors and attitudes towards immigrants.

\section{References}

Allport, Gordon W. (1958): The nature of prejudice: Cambridge: Addison Wesley.

Andersen, Robert, and Tina Fetner (2008) Economic inequality and intolerance: Attitudes toward homosexuality in 35 democracies. American Journal of Political Science 52(4): 942-958.

Baron, Robert A. (1989) Psychology. Boston: Allyn \& Bacon.

Berry, William D., Matt Golder and Daniel Milton (2012) Improving Tests of Theories Positing Interaction. The Journal of Politics 74(3): 653-671.

Boeri, Tito, Gordon Hanson, and Barry McCormick (2002) Immigration policy and the welfare system: a report for the Fondarione Rodolfo Debenedetti. Oxford: Oxford University Press.

Clarke, Kevin A. (2012) More Phantom Than Menace. Conflict Management and Peace Science 29(2): 239-241.

Clayton, Richard, and Jonas Pontusson (1998) Welfare-State Retrenchment Revisited: Entitlement Cuts, Public Sector Restructuring, and Inegalitarian Trends in Advanced Capitalist Societies. World Politics 51(1): 67-98.

Crepaz, Markus M. L., and Regan Damron (2009) Constructing Tolerance: How the Welfare State Shapes Attitudes about Immigrants. Comparative Political Studies 42(3): 437-463.

Dunn, Kris, Salomon Orellana, and Shane Singh (2009) Legislative Diversity and Social Tolerance: How Multiparty Systems Lead to Tolerant Citizens. Journal of Elections, Public Opinion \& Parties 19(3): 283-312.

Eger, Maureen A. (2010) Even in Sweden: the Effect of Immigration on Support for Welfare State Spending. European Sociological Review 26(2): 203-217.

Emmenegger, Patrick, and Robert Klemmensen (2013) Immigration and redistribution revisited: how different motivations can offset each other. Journal of European Social Policy 23(4): 406-422.

Esping-Andersen, Gøsta. 1990. The Three Worlds of Welfare Capitalism. Princeton: Princeton University Press.

Feldmann, Eva, Thomas R. Henschel, and Susanne Ulrich (2000) Tolerance. Basis for Democratic Interaction. Ed. Bertelsmann Group for Policy Research. Gütersloh: Verlag Bertelsmann Stiftung, 133.

Ferrar, Jane W. (1976) The Dimensions of Tolerance. The Pacific Sociological Review 19(1): 63-81.

Finseraas, Henning (2008) Immigration and Preferences for Redistribution: An empirical Analysis of European Survey Data. Comparative European Politics 6: 407-431.

Forst, Rainer (2003) Toleration, justice and reason. In The Culture of Toleration in Diverse Societies, eds. Catriona McKinnon and Dario Castiglione. Manchester: Manchester University Press, 71-85. 
Forst, Rainer (2007) Toleration. In Stanford Encyclopedia of Philosophy (Vol. 11). Stanford: Stanford University, 312-325.

Freitag, Markus (2006) Bowling the State Back in. Political Institutions and the Creation of Social Capital. European Journal of Political Research 45(1): 123-152.

Freitag, Markus, and Carolin Rapp (2013) Intolerance Toward Immigrants in Switzerland. Diminished Threat Through Social Contacts? Swiss Political Science Review, 19(4): 425-446.

Fritzsche, Peter K. (1995) Toleranz im Umbruch. Über die Schwierigkeit, tolerant zu sein. Aus Politik und Zeitgeschichte B43: 8-17.

Gibson, James L. (1992) Alternative Measures of Political Tolerance - Must Tolerance be 'least-liked'? American Journal of Political Science 36(2): 560-77.

Gibson, James L. (2006) Enigmas of Intolerance: Fifty Years after Stouffer's Communism, Conformity, and Civil Liberties. Perspectives on Politics 4 (1):21-34.

Gibson, James L. (2013) Measuring Political Tolerance and General Support for Pro-Civil Liberties Policies. Notes, Evidence, and Cautions. Public Opinion Quarterly 77 (Special Issue): 45-68.

Gibson, John L., and Amanda Gouws (2000) Social Identities and Political Intolerance: Linkages within the South African Mass Public. American Journal of Political Science 44(2): 278-292.

Hall, Peter A., and Rosemary C. R. Taylor (1996) Political Science and the Three New Institutionalisms. Political Studies 44:936-957.

Heckman, James J. (1979) Sample Selection Bias as a Specification Error. Econometrica 47(1): 153-161.

Hjerm, Mikael (2009) Anti-Immigrant Attitudes and Cross-Municipal Variation in the Proportion of Immigrants. Acta Sociologica 52(1): 47-62.

Huckfeldt, Robert R. (1986) Politics in Context: Assimilation and Conflict in Urban Neighborboods. New York: Agathon Press.

King, Preston (1998) Toleration. London/Portland: Frank Cass Publishers.

Kirchner, Antje, Markus Freitag, and Carolin Rapp (2011) Crafting tolerance: the role of political institutions in a comparative perspective. European Political Science Review 3 (2): 201-227.

Larsen Christian A. (2008) The institutional logic of welfare attitudes: How welfare regimes influence public support. Comparative Political Studies 41(2): 145-169.

Lijphart, Arend (1999) Patterns of Democracy. Government Forms and Performance in Thirty-Six Countries. New Haven/ London: Yale University Press.

Marquart-Pyatt, Sandra, and Pamela Paxton (2007) In Principle and in Practice: Learning Political Tolerance in Eastern and Western Europe. Political Behavior 29(1): 89-113.

Mau, Steffen, and Christoph Burkhardt (2013) Migration and welfare state solidarity in Western Europe. Journal of European Social Policy 19(3): 213-229.

Mclaren, Lauren (2003) Anti-Immigrant Prejudice in Europe: Contact, threat Perception, and Preferences for the Exclusion of Migrants. Social Forces 81(3): 909-936.

van der Meer, Tom, Manfred Te Grotenhuis, and Ben Pelzer (2010) Influential Cases in Multilevel Modeling: A Methodological Comment. American Sociological Review 75(1): 173-178.

Melich, Anna (1997) Eurobaromter 47.1: Images of Switzerland, Education Throughout Life, Racism, and Patterns of Family Planning and Work Status, March-April 1997 [Computer File].

Mondak, Jeffrey J., and Mitchell S. Sanders (2003) Tolerance and Intolerance, 1976-1998. American Journal of Political Science 47(3): 492-502.

Mutz, Diana C. (2001) Tolerance. In International Encyclopedia of the Social \& Behavioral Sciences, ed. N. J. Smelser and P. B. Baltes. Amsterdam: Elsevier, Vol. 23 pg.15766-15771

Nannestad, Peter (2007) Immigration and welfare states. A survey of 15 years research. European Journal of Political Economy 23: 512-532. 
Nevitte, Neil (1996) Tolerance and intolerance in advanced industrial states: the cross-time evidence. ed. L. Halman and N. Nevitte. Political value change in western democracies. Integration, values, identification, and participation. Tilburg: Tilburg University Press.

Norris, Pippa (2002) Democratic phoenix: Reinventing political activism. Cambridge: Cambridge University Press.

van Oorschot, Wim, and Wilfred Uunk. 2007. Welfare Spending and the Public's Concern for Immigrants: Multilevel Evidence for Eighteen European Countries. Comparative Politics 40(1): 63-82.

Peffley, Mark, and Robert Rohrschneider (2003) Democratization and Political Tolerance in Seventeen Countries: A Multi-level Model of Democratic Learning. Political Research Quarterly 56(3): 243-257.

Quillian, Lincoln (1995) Prejudice as a Response to Perceived Group Threat: Population Composition and Anti-Immigrant and Racial Prejudice. American Sociological Review 60(4): 209-233.

Rothstein, Bo, and Dietlind Stolle (2008) The State and Social Capital: An Institutional Theory of Generalized Trust. Comparative Politics 40(4): 441-467.

Rothstein, Bo, and Eric M. Uslaner (2005) All for all. Equality, Corruption and Social Trust. World Politics 58: 41-72.

Scanlon, Thomas M. (2003) The difficulty of tolerance: essays in political philosophy. Cambridge: Cambridge University Press.

Scheepers, Peer, Merove Gijsberts, and Marcel Coenders (2002) Ethnic Exclusionism in European Countries. Public Opposition to Civil Rights for Legal Migrants as a Response to Perceived Ethnic Threat. European Sociological Review 18(1): 17-34.

Schneider, Silke L. (2008) Anti-Immigrants Attitudes in Europe: Outgroup Size and Perceived Ethnic Threat. European Sociological Review 24(1): 53-67.

Sniderman, Paul M., Philip E. Tetlock, James M. Glaser, Donald Philip Green and Michael Hout (1989) Principled Tolerance and the American Mass Public. British Journal of Political Science, 19(1): 25-45.

Stegmueller, Daniel (2013) How Many Countries for Multilevel Modeling? A Comparison of Frequentist and Bayesian Approaches. American Journal of Political Science 57(3): 748-761.

Stouffer, Samuel A. (1955) Communism, conformity, and civil liberties: A cross-section of the nation speaks its mind. New Brunswick: Transaction Publishers.

Sullivan, John L., James Piereson, and George E. Marcus (1993) Political Tolerance and American Democrayy. Chicago: The University Of Chicago Press.

Tajfel, Henri (1982) Social Psychology of Intergroup Relations. Annual Review of Psychology 33(1): 1-39.

Tajfel, Henri and John C. Turner (1979) An integrative theory of intergroup conflict, in: William G. Augstein and Stephan Worchel (eds.), The Social Psychology of Intergroup Relations. Monterey: Brooks/Cole, 33-47.

Tatalovich, Raymond, and T. Alexander Smith (2001) Status Claims and Cultural Conflicts: The Genesis of Morality Policy. Policy Currents 10 (4): 2-8.

Vella, Francis (1998) Estimating Models with Sample Selection Bias: A Survey. Journal of Human Resources 33: $127-169$.

van der Waal, Jeroen, Willem De Koster, and Wim van Oorschot (2013) Three Worlds of Welfare Chauvinism? How Welfare Regimes Affect Support for Distributing Welfare to Immigrants in Europe. Journal of Comparative Policy Analysis 15(2): 164-181.

Weldon, Steven A. (2006) The institutional context of tolerance for ethnic minorities: A comparative, multilevel analysis of western Europe. American Journal of Political Science 50(2): 331-349.

Winship, Christopher, and Robert D. Mare (1992) Models for Selection Bias. Annual Review of Sociology 18: 327-350. 


\section{Appendix}

Table A1: Variables description

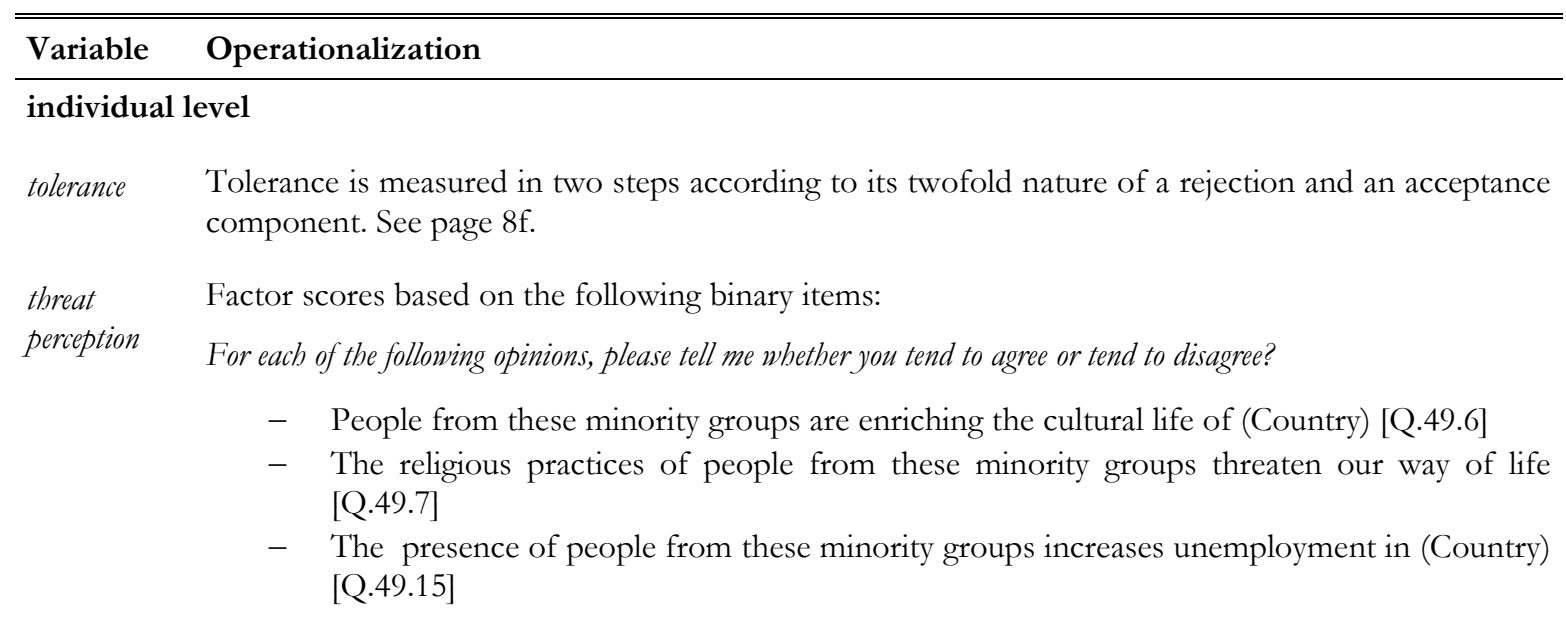

ML-factor analysis based on a tetrachoric correlation matrix as the items are binary coded [0/1]. Items were recoded so that they are all directed in the same direction.

number of Do you have many friends, some friends or no friends at all amongst people from these minority groups? [Q.51];

foreigners $1=$ many, $2=$ some, $3=$ none

among

friends

$\operatorname{sex}$

Dummy variable with $0=$ male and $1=$ female $[\mathrm{D} .10]$

age

How old are you? [Q.11]

education How old were you when you stopped full-time education? [D.8]

political In political matters people talk of "the left" and "the right". How would you place your views on this scale? [D.1]

ideology

\section{contextual level}

health care Total public and mandatory private expenditure on health as a percentage of GDP in 1995. Source: expenditure Comparative Political Data Set.

in $\%$ of

GDP

[http://www.ipw.unibe.ch/content/team/klaus_armingeon/comparative_political_data_sets/index_en g.html]

unemploymen Cash expenditure for unemployment benefits as a percentage of GDP (public and mandatory private) texpenditure in 1995. Source: Comparative Political Data Set.

in \% of [http://www.ipw.unibe.ch/content/team/klaus_armingeon/comparative_political_data_sets/index_en GDP g.html]

ethnic Ethnic composition of a country is measured according to the Herfindahl Index based on the following diversity formula: $H I=1-\sum_{i=1}^{N} s_{i j}^{2}$, where $s_{i j}^{2}$ is the share of the group i ( $\mathrm{i}=1 \ldots \mathrm{n}$ ) in country $\mathrm{j}$. The (ethnic) Herfindahl Index measures the probability that two randomly chosen individuals in country $j$ are different with regard to their ethnicity. The index ranges from 0 to 1 , whereby higher values indicate higher ethnic heterogeneity. Source: Worldbank [http://econ.worldbank.org], data for 1995.

$(\log )$ GDP Gross Domestic Product in 1995. Source: Comparative Political Data Set.

[http://www.ipw.unibe.ch/content/team/klaus_armingeon/comparative_political_data_sets/index_en g.html] 
Table A2: First-stage regression results

selection stage regression

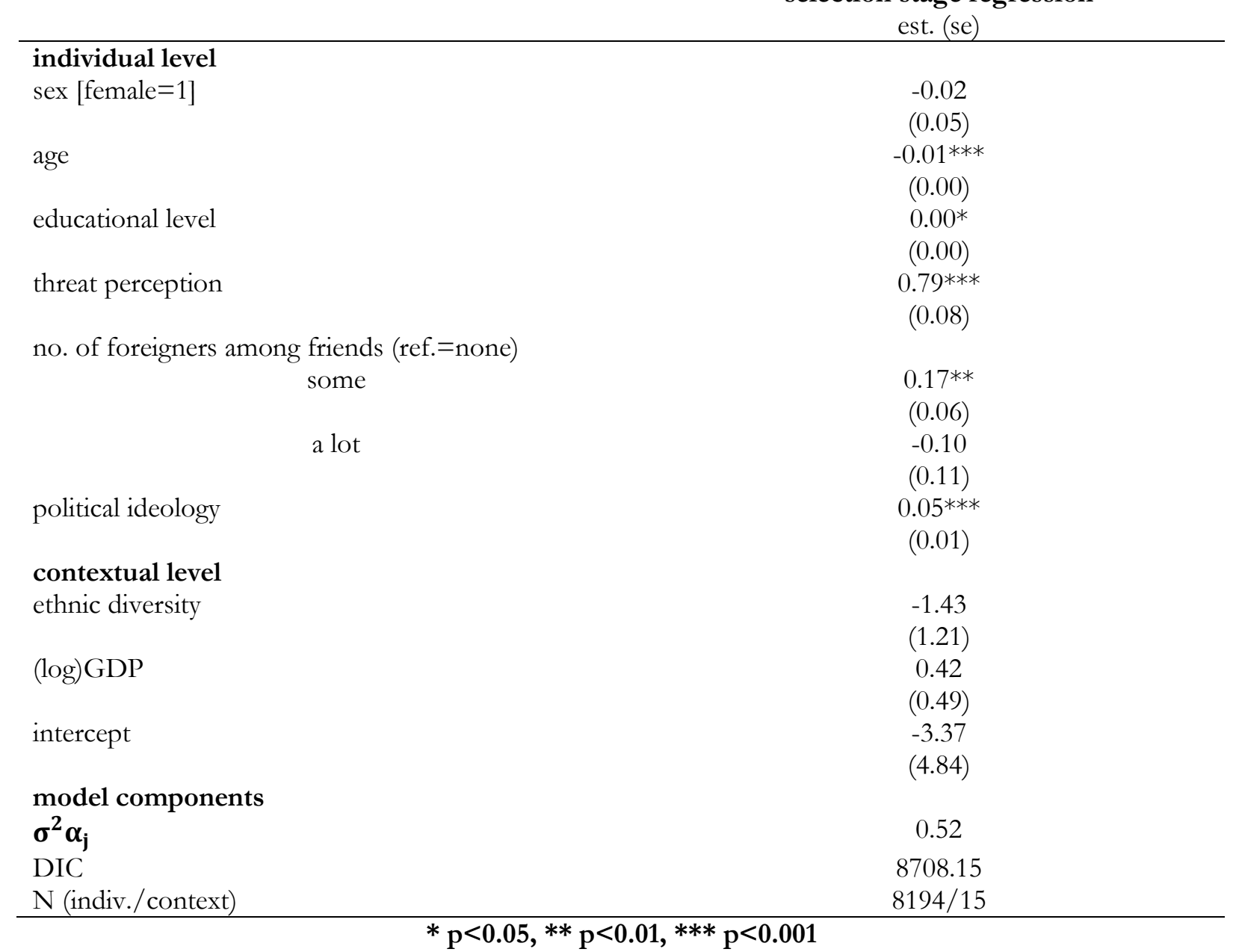


Table A3: Social and political tolerance - additional estimates with total social expenditures in $\%$ of the GDP

\begin{tabular}{|c|c|c|}
\hline & $\begin{array}{l}\text { social tolerance } \\
\text { est. (se) }\end{array}$ & $\begin{array}{c}\text { political tolerance } \\
\text { est. (se) }\end{array}$ \\
\hline \multicolumn{3}{|l|}{ individual level } \\
\hline threat perception & $\begin{array}{c}-2.21 * * * \\
(0.11)\end{array}$ & $\begin{array}{c}-1.81 * * * \\
(0.10)\end{array}$ \\
\hline \multicolumn{3}{|c|}{ no. of foreigners among friends (ref.=none) } \\
\hline some & $\begin{array}{c}0.33^{* * *} \\
(0.05)\end{array}$ & $\begin{array}{c}0.19 * * * \\
(0.04)\end{array}$ \\
\hline a lot & $\begin{array}{c}0.89 * * * \\
(0.08)\end{array}$ & $\begin{array}{c}0.32 * * * \\
(0.08)\end{array}$ \\
\hline political ideology & $\begin{array}{c}-0.12^{* * *} \\
(0.01)\end{array}$ & $\begin{array}{c}-0.05^{* * * *} \\
(0.00)\end{array}$ \\
\hline inverse Mills ratio & $\begin{array}{c}-3.46^{* * *} \\
(0.41)\end{array}$ & $\begin{array}{c}-1.35^{* * * *} \\
(0.39)\end{array}$ \\
\hline \multicolumn{3}{|l|}{ contextual level } \\
\hline total social exp. & $0.05^{*}$ & 0.04 \\
\hline in $\%$ of GDP & $(0.02)$ & $(0.03)$ \\
\hline ethnic diversity & $\begin{array}{l}9.33 * * * \\
(2.65)\end{array}$ & $\begin{array}{l}9.56 * * \\
(3.08)\end{array}$ \\
\hline$(\log )$ GDP & $\begin{array}{c}-0.73^{* * *} \\
(0.22)\end{array}$ & $\begin{array}{l}-0.69 * * \\
(0.25)\end{array}$ \\
\hline \multicolumn{3}{|l|}{ interaction effects } \\
\hline total soc.exp.* & $-0.33^{* *}$ & $-0.41 * * *$ \\
\hline ethnic div. & $(0.11)$ & $(0.10)$ \\
\hline intercept & $\begin{array}{c}11.45^{* * *} \\
(1.89)\end{array}$ & $\begin{array}{c}11.39 * * * \\
(2.10)\end{array}$ \\
\hline \multicolumn{3}{|l|}{ model components } \\
\hline$\sigma^{2} \alpha_{j}$ & 0.02 & 0.04 \\
\hline$\sigma^{2}$ & 2.05 & 1.80 \\
\hline DIC & 20989.9 & 20063.4 \\
\hline $\mathrm{N}$ (indiv./context) & $5895 / 15$ & $5895 / 15$ \\
\hline
\end{tabular}

Figure A1: The influence of total social expenditures on social and political tolerance for different levels of ethnic heterogeneity
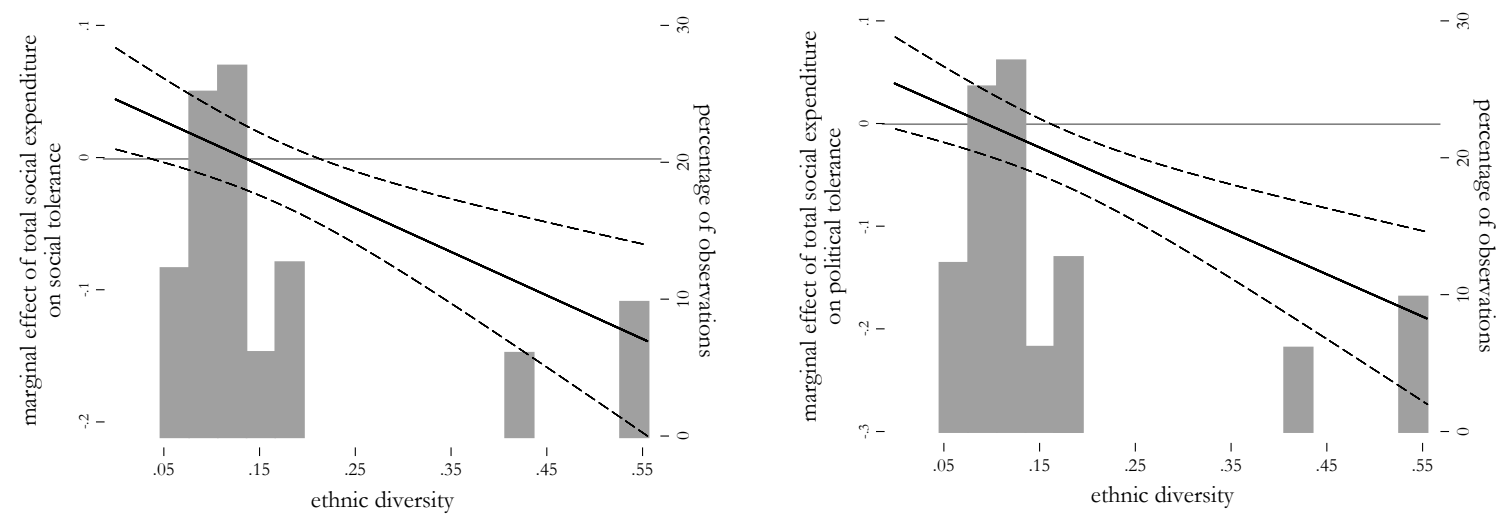